\title{
Peel and pulp of baru (Dipteryx Alata Vog.) provide high fiber, phenolic content and antioxidant capacity
}

\author{
Gabriela de Lima SANTIAGO ${ }^{1}$, Ingryd Garcia de OLIVEIRA ${ }^{1}$, Maria Aderuza HORST ${ }^{1}$, \\ Maria Margareth Veloso NAVES ${ }^{1}$, Mara Reis SILVA ${ }^{1 *}$
}

\begin{abstract}
Baru (Dipteryx alata Vog.) is a native fruit of the Brazilian Savannah that can be used in the food industry and may contribute to the economy of the Brazilian Midwest. The proximate composition, the phenolic content and the antioxidant capacity of the peel, pulp and raw and roasted baru almond were examined and compared. Peel showed higher concentrations of dietary fibers $(24.1 \mathrm{~g} / 100 \mathrm{~g})$ followed by pulp and roasted almond $(18 \mathrm{~g} / 100 \mathrm{~g}$ and $16 \mathrm{~g} / 100 \mathrm{~g}$, respectively), and raw almond $(12.0 \mathrm{~g} / 100 \mathrm{~g})$. However, the almonds presented the highest lipid and protein concentrations compared to baru peel and pulp. In addition, raw almond showed the highest total phenolic contents $(1,107.0 \mathrm{mg} \mathrm{GAE} / 100 \mathrm{~g})$ and antioxidant capacity, but the roasted almond, and baru peel with its pulp, also presented high phenolic contents. The correlation coefficients between phenolic content and antioxidant capacity (via ABTS and FRAP) were strong and significant. The chemical composition of baru peel has not previously been reported. The results showed promising prospects for the consumption of baru pulp with its peel, the fruit component richest in fiber, whose phenolic content and antioxidant capacity are comparable to those of the baru almond.
\end{abstract}

Keywords: phytochemicals; nutrients; fruit; Cerrado.

Practical Application: Baru pulp with its peel has a promising prospect as a food ingredient due to their high amounts of fiber, phenolic content and antioxidant capacity. Therefore, the whole baru fruit represents an attractive option for consumers and food industries.

\section{Introduction}

The Cerrado is the second largest biome in Brazil and the richest Savannah in the world, and it is considered one of the worldwide hotspots for the conservation of biodiversity It has diverse natural resources, especially native fruits with high nutritional value and sensory appeal, which can be eaten fresh or processed (Vieira et al., 2010). The baru plant (Dipteryx alata Vog) is a good example of Cerrado native species.

The fruit of the baru tree is a drupe that contains one seed known as baru almond (Figure 1). The roasted seed can be eaten or used as an ingredient in the local gastronomy, replacing the cashew nut, peanut or other oilseeds. Baru almond is used as a raw material for small and medium-sized food industries, which contributes to the economy of the Brazilian Midwest (Collevatti et al., 2013). Baru pulp is covered by a thin light-brown peel and has a sweet taste, but it is less frequently consumed than the almond. Nevertheless, peel and pulp have been included in some recipes for breads, cakes and cereal bars (Lima et al., 2010; Rocha \& Santiago, 2009; Vieira et al., 2010).

Baru almond has been reported as rich in good quality protein, lipids (especially oleic acid), fibers and minerals (Fernandes et al., 2015; Fernandes et al., 2010). Besides, the almond has been picked out as a good source of antioxidant nutrients

(Fernandes et al., 2015) and other bioactive compounds, such as phenolic compounds (Lemos et al., 2012). In contrast, there are comparatively few data about the chemical composition of baru pulp, but it has been reported that it contains high concentrations of sugars, fibers and minerals (Freitas et al., 2014). No scientific study about the proximate composition of baru peel, separated from the pulp, has been found in the literature up to now.

Studies have shown that phenolic compounds have anti-inflammatory, anti-proliferative and anti-infectious properties, as well as exerting a protective effect against oxidative stress related to diabetes, cancer, cardiovascular and neurodegenerative diseases (Del Rio et al., 2013). Considering the applicability of baru peel and pulp in processed foods for human consumption and the health-benefits of phenolic compounds, it is worth studying the nutrients and phenolic content of the whole baru fruit, including its peel and pulp. The chemical characterization of peel and pulp, compared to the almond, can stimulate the consumption of whole fruit and the economic investments on processed foods with baru. Thus, the aim of this study was to evaluate the proximate composition, the total phenolic contents and the antioxidant capacity of the peel and pulp of baru fruit compared to raw and roasted baru almonds. 


\section{Materials and methods}

\subsection{Fruit collection and sample processing}

Baru fruit was collected in the outskirts of Senador Canedo county (Goiás State, Brazil), during the maturation period, after natural fall from the tree. The fruits were peeled by hand, and half the almonds were roasted using a conventional electric oven at $140{ }^{\circ} \mathrm{C}$ for $30 \mathrm{~min}$ (Fernandes et al., 2010), and the other half remained raw, both with skin. Peel, pulp, raw and roasted almonds (Figure 1) were ground separately using a domestic multiprocessor, vacuum packed and then stored at $-18^{\circ} \mathrm{C}$ until analysis.

\subsection{Proximate composition analysis and energy value estimation}

The moisture was determined by drying samples at $105^{\circ} \mathrm{C}$, and ash was obtained by incineration in an oven at $550{ }^{\circ} \mathrm{C}$ (Association of Official Analytical Chemists, 2010). The nitrogen content was analyzed by micro-Kjeldahl method and converted to crude protein using the factor 6.25 (Association of Official Analytical Chemists, 2010). Total lipids were determined as described by Bligh \& Dyer (1959). Total dietary fiber was measured by Association of Official Analytical Chemists (2010), and the carbohydrate was estimated by difference, subtracting the values obtained for moisture, ash, protein, lipids, and dietary fiber from one hundred. The energy value of the samples was determined using the Atwater conversion factors of $4 \mathrm{kcal} / \mathrm{g}$ for proteins and carbohydrates, and $9 \mathrm{kcal} / \mathrm{g}$ for lipids. The analyses were performed in triplicate.

\subsection{Evaluation of total phenolic compounds and antioxidant capacity}

Sample extracts were obtained according to the method described by Zhang et al. (2014), with modifications. Raw and roasted samples of baru almond $(0.05 \mathrm{~g})$, peel and pulp $(0.1 \mathrm{~g})$ were dissolved in $10 \mathrm{~mL}$ of $50 \%$ ethanol solution. This mixture was vortexed for 30 seconds and then homogenized in an automatic shaker for $1 \mathrm{~h}$. The solution was centrifuged at $18^{\circ} \mathrm{C}$ and $5000 \mathrm{rpm}$ for $10 \mathrm{~min}$. The supernatant was filtered for the investigation of the phenolic compounds and antioxidant capacity.

The phenolic contents were performed according to Singleton \& Rossi (1965), with adaptations. An aliquot of $0.25 \mathrm{~mL}$ of the extract was mixed with $0.25 \mathrm{~mL}$ of the solution of Folin Ciocalteu reagent (1:2) and $2.5 \mathrm{~mL}$ of bi-distilled water. After standing for $5 \mathrm{~min}$ at room temperature, $0.25 \mathrm{~mL}$ of sodium carbonate solution (10\%) was added and the mixture was placed at rest for $60 \mathrm{~min}$, at room temperature, and protected against light. The absorbance was measured at $765 \mathrm{~nm}$ using the UV/Vis V-630 spectrophotometer (Jasco, Tokyo, Japan). The results were expressed as milligrams of gallic acid equivalent per $100 \mathrm{~g}$ (mg GAE/100 g) of the sample (fresh weight).

The test of antioxidant potential by ABTS method (ABTS 2,2'-Azino-bis (3-ethylbenzothiazoline-6-sulfonate) was performed as described by Re et al. (1999), with modifications.
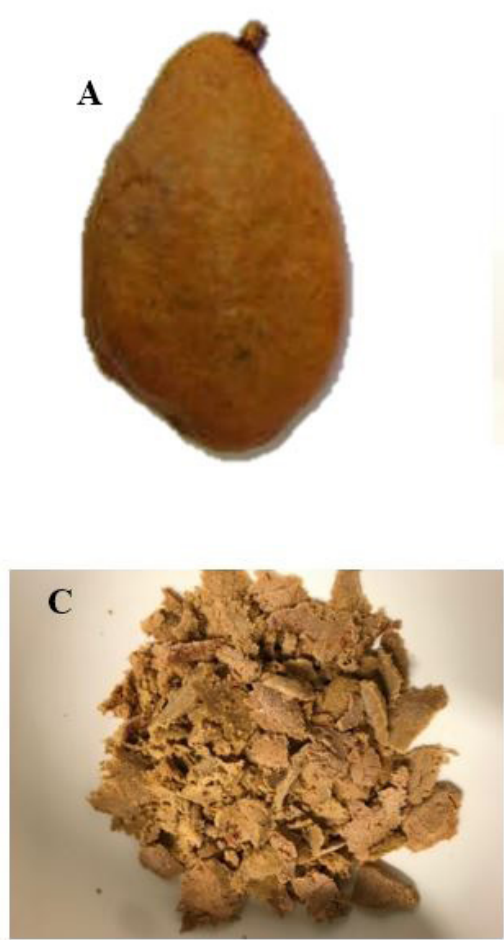
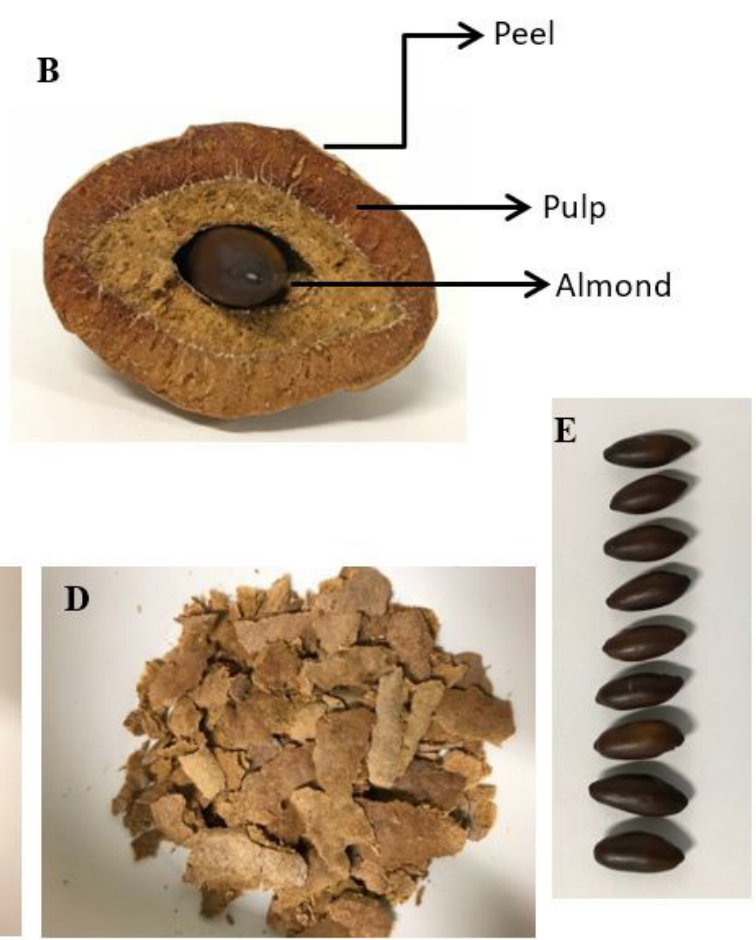

Figure 1. Baru fruit components: A) whole fruit; B) fruit with sectioned parts; C) baru pulp; D) baru peel; E) different sizes of the baru almond (with skin). 
The ABTS radical was formed from the reaction of $140 \mathrm{mM}$ potassium persulfate with $7 \mathrm{mM}$ ABTS stock solution, kept at room temperature and protected against light for $16 \mathrm{~h}$. Subsequently, a $30 \mu \mathrm{L}$ aliquot of each extract was homogenized with $3 \mathrm{~mL}$ of the ABTS radical. After incubation for $6 \mathrm{~min}$ at room temperature, the absorbance was read at $734 \mathrm{~nm}$ and the results were expressed in Trolox equivalents per gram $(\mu \mathrm{mol}$ $\mathrm{TE} / \mathrm{g}$ ) of sample (fresh weight).

The DPPH (2,2-diphenyl-1-picryl-hidrazila) radical scavenging method was carried out according to Brand-Williams et al. (1995), with modifications. An aliquot of $0.1 \mathrm{~mL}$ of sample extract was dissolved with $3.9 \mathrm{~mL}$ of the DPPH solution $(60 \mathrm{mmol} / \mathrm{L})$, and kept at room temperature, protected against light, for $120 \mathrm{~min}$. The absorbance was measured at $515 \mathrm{~nm}$. The trolox standard curve was built from the inhibition percentage versus the trolox concentration $(50 \mathrm{mg} / \mathrm{L}$ to $250 \mathrm{mg} / \mathrm{L})$. The values were expressed in Trolox equivalents per gram $(\mu \mathrm{mol} \mathrm{TE} / \mathrm{g})$ of sample (fresh weight).

The FRAP (Ferric Reducing Antioxidant Power) assay was performed as previously described by Benzie \& Strain (1996). An aliquot of $90 \mathrm{uL}$ extract reacted with $2.7 \mathrm{~mL}$ of FRAP reagent (0.3 M, pH 3.6 acetate buffer, $10 \mathrm{mM}$ TPTZ and $20 \mathrm{mM}$ ferric chloride) and $270 \mathrm{uL}$ of ultra-pure water. This mixture was incubated at $37^{\circ} \mathrm{C}$ for $30 \mathrm{~min}$. Afterwards, the absorbance was read at $595 \mathrm{~nm}$, and the results were expressed as $\mu \mathrm{mol}$ of trolox equivalents per gram ( $\mu \mathrm{mol} \mathrm{TE} / \mathrm{g}$ ) of sample (fresh weight). Trolox was used as the standard for the calibration curve, in concentrations that varied from $100 \mu \mathrm{mol} / \mathrm{L}$ to $800 \mu \mathrm{mol} / \mathrm{L}$.

\subsection{Statistical analysis}

Values are given as mean and standard deviation of three replicates. Analysis of variance (ANOVA) and test for mean comparisons (Tukey, 5\% probability) were performed. The correlation between total phenolic contents and antioxidant capacity was analyzed by using the Pearson's correlation coefficient with $5 \%$ probability. Statistical calculations were performed using the statistical packages Action (StatCamp, São Carlos, Brazil) and Statistica 7.0.

\section{Results and discussion}

\subsection{Proximate composition}

Baru peel showed the highest content of dietary fiber, and the pulp presented the highest concentration of carbohydrates. The almonds had the highest energy values due to their high amount of lipids. The high concentration of proteins in the raw and roasted almonds is also noteworthy (Table 1).

There is no information about the chemical composition of baru peel, separated from the pulp, in the literature. The high amount of fiber in baru peel (Table 1) is due to the presence of cellulose, lignin and hemicellulose, which are the main components of the fruit epicarps (Marques et al., 2010). In general, carbohydrate is the highest nutrient in the fruit pulp, and baru pulp predominantly contains sugars $(23 \mathrm{~g} / 100 \mathrm{~g})$ and fibers $(20 \mathrm{~g} / 100 \mathrm{~g})$, the contents of which increase during the storage period of the baru fruit (Alves et al., 2010). The amount of the total carbohydrates found in the present study was slightly lower, and the dietary fiber content was higher than that of the baru pulp studied by Alves et al. (2010) (Table 1). Probably, the profile of carbohydrates varies according to the region the baru fruit comes from and its degree of maturity.

Baru peel has the potential to be included in the human diet due to its high amount of fiber and to its soft texture. The use of baru pulp with its peel can improve the nutritional and functional profiles of processed foods, by increasing the fiber and phenolic contents and decreasing the energy value (Lima et al., 2010; Rocha \& Santiago, 2009). The roasted baru almond had higher concentrations of all components analyzed than the raw almond, except for carbohydrates (Table 1). This fact can be explained by the difference between the moisture contents of the raw $(9.9 \mathrm{~g} / 100 \mathrm{~g})$ and roasted $(6.8 \mathrm{~g} / 100 \mathrm{~g})$ almonds. Compared to all the baru components, the almond showed the highest amounts of protein and lipid. The protein and lipid concentrations in raw and roasted almonds were lower than those observed in other studies (Table 1). Nevertheless, the difference between moisture contents may have influenced these results.

The protein content of the baru almond was higher than that of many edible seeds and nuts studied by Freitas \& Naves

Table 1. Proximate composition and energy value of the peel, pulp, and raw and roasted almonds of the baru fruit compared to the literature data.

\begin{tabular}{|c|c|c|c|c|c|c|c|c|}
\hline \multirow{2}{*}{ Baru sample } & \multicolumn{6}{|c|}{ Component $(\mathrm{g} / 100 \mathrm{~g})$} & \multirow{2}{*}{$\begin{array}{c}\text { Energy value } \\
(\mathrm{kcal} / 100 \mathrm{~g})\end{array}$} & \multirow{2}{*}{ Reference } \\
\hline & Moisture & Protein & Lipid & Carbohydrate & Dietary fiber & Ash & & \\
\hline Peel & $16.3^{\mathrm{a}} \pm 0.4$ & $2.5^{\mathrm{d}} \pm 0.1$ & $2.7^{\mathfrak{c}} \pm 0.2$ & $51.5^{\mathrm{b}} \pm 0.7$ & $24.1^{a} \pm 0.5$ & $2.9^{\mathrm{b}} \pm 0.1$ & $240^{c} \pm 3$ & Present study \\
\hline Pulp & $14.9^{\mathrm{b}} \pm 0.1$ & $3.2^{c} \pm 0.1$ & $3.7^{\mathfrak{c}} \pm 0.1$ & $57^{a} \pm 2$ & $18^{\mathrm{b}} \pm 2$ & $3.1^{\mathrm{a}} \pm 0.1$ & $276^{\mathrm{b}} \pm 6$ & Present study \\
\hline Raw almond & $9.9^{c} \pm 0.1$ & $21.3^{\mathrm{b}} \pm 0.1$ & $36.3^{\mathrm{b}} \pm 1.4$ & $18^{\mathrm{c}} \pm 1$ & $12.0^{c} \pm 0.4$ & $2.7^{\mathfrak{c}} \pm 0.1$ & $483^{\mathrm{a}} \pm 1$ & Present study \\
\hline Roasted almond & $6.8^{\mathrm{d}} \pm 0.1$ & $22.9^{\mathrm{a}} \pm 0.2$ & $40.6^{\mathrm{a}} \pm 1.1$ & $11^{\mathrm{d}} \pm 1$ & $16^{\mathrm{b}} \pm 1$ & $3.1^{\mathrm{a}} \pm 0.0$ & $501^{a} \pm 9$ & Present study \\
\hline \multicolumn{9}{|l|}{ Literature data } \\
\hline Pulp & $13.8 \pm 0.6$ & $4.2 \pm 0.7$ & $3.7 \pm 0.1$ & 54.9 & $19.1 \pm 0.2$ & $4.3 \pm 0.3$ & 269.8 & Alves et al. (2010) \\
\hline Raw almond & $6.1 \pm 0.2$ & $23.9 \pm 0.6$ & $38.2 \pm 0.4$ & $15.8 \pm 0.6$ & $13.4 \pm 0.3$ & $2.7 \pm 0.1$ & $502 \pm 3$ & Takemoto et al. (2001) \\
\hline \multirow[t]{4}{*}{ Roasted almond } & $3.7 \pm 0.3$ & $26 \pm 2$ & $42 \pm 2$ & 13.6 & $11.6 \pm 0.2$ & $3.3 \pm 0.1$ & 535.4 & Fernandes et al. (2010) \\
\hline & $3.2 \pm 0.1$ & $28.9 \pm 0.3$ & $42.4 \pm 0.6$ & 10.8 & $11.7 \pm 0.2$ & $3.0 \pm 0.0$ & $574 \pm 6$ & Fernandes et al. (2015) \\
\hline & $3.6 \pm 0.2$ & $31 \pm 1$ & $41 \pm 2$ & $9 \pm 2$ & $12 \pm 1$ & $3.0 \pm 0.1$ & $532 \pm 12$ & Czeder et al. (2012) \\
\hline & $3.5 \pm 0.1$ & $29.9 \pm 0.4$ & $41.9 \pm 0.4$ & 12.2 & $9.2 \pm 0.2$ & $3.2 \pm 0.0$ & 546.2 & Sousa et al. (2011) \\
\hline
\end{tabular}

Values are means \pm standard deviation $(n=3)$. In the same column, means with different letters differ significantly by Tukey test ( $\mathrm{p} \leq 0.05)$. 
(2010). Moreover, it is important to mention that the baru almond has good-quality protein, as demonstrated by the results of Net Protein Ratio (NPR) and Protein Digestibility-Corrected Amino Acid Score (PDCAAS) biological indices (Fernandes et al., 2010; Freitas \& Naves, 2010). Concerning the lipid content of the baru almond, it was lower than that reported for nine out of ten edible seeds and nuts (42.1 to $66.2 \mathrm{~g} / 100 \mathrm{~g}$ ) (Freitas \& Naves, 2010). Consequently, the baru almond has a lower energy value compared to other oilseeds, such as Brazil nut, cashew nut, hazelnut, pecan and pistachios (Freitas \& Naves, 2010). Besides, the lipids of the baru almond have a healthy fatty acid profile, with high unsaturated to saturated fatty acids ratio (5.4:1) (Alves et al., 2016). The carbohydrate content of the baru almond was higher than those reported in the literature (Fernandes et al., 2010; Sousa et al., 2011; Takemoto et al., 2001) (Table 1). The dietary fiber content indicates that the baru almond is a good source of fiber. However, the combination of baru pulp and its peel has a higher concentration of dietary fiber than the almond.

The variations between the baru composition described in our study and the literature data (Table 1) can be mainly explained by the moisture content differences. The moisture variation can be result of the differences in the environmental conditions during the period of the baru harvest, such as rainfall and relative humidity variations, and the storage conditions of the fruit.

\subsection{Total phenolic content and antioxidant capacity}

The baru almond showed the highest phenolic content and can be considered a high source of phenolics, but the raw almond had around 50\% more phenolics than the roasted almond (Table 2). The effect of heat treatment applied to foods, such as roasting, causes evaporation of intracellular water, which can result in increased availability of nutrients and bioactive compounds in the matrix (Mazzeo et al., 2011). However, according to our results, the roasting caused a reduction of $34 \%$ in the phenolic content of the baru almond. In contrast, previous report (Lemos et al., 2012) showed that the value of polyphenols in the raw almond (568.9 mg GAE. $100 \mathrm{~g}$ ) was almost the same as that of the roasted baru almond (531.8 mg GAE/100 g), and both values were lower than those found in our study (Table 2). These differences may be due to genetic variability that affects baru almond phenotype (Soares et al., 2008), and because of the different conditions used for total phenolic extraction.
Baru peel presented a higher total phenolic content than that of the pulp, in line with what has been reported for other native fruits (Omena et al., 2012). Fruit peel usually has more phenolics than the pulp, since these compounds are natural metabolites, which protect plants against external aggressive agents (Crozier et al., 2009). Baru pulp can also be considered a good source of phenolics compared to conventional fruits. Chen et al. (2014) analyzed pulp from 33 fruits, and 31 showed lower phenolic contents than that of baru pulp. On the other hand, Souza et al. (2012) found higher concentrations of phenolics in the pulps of two Cerrado native fruits: marolo (789.4 mg GAE/100 g) and murici (334.4 mg GAE/100 g). The amount of total phenolic compounds of the pulp with peel (769.2 mg GAE/100 g) is close to that found in the roasted baru almond, and higher than the values reported for 10 popularly consumed Brazilian fruits, including red grape (Vitis vinífera L.) and açaí (Euterpe oleracea) (Koehnlein et al., 2016). Therefore, the use of baru pulp with its peel should be considered as a by-product with potential health-benefits.

Vasco et al. (2008) analyzed the total phenolic compounds of 17 fruits from Ecuador and reported that only blackberry, cherry peel, banana and passion fruit had contents above $1000 \mathrm{mg}$ GAE/100 g. These authors classified the fruits with content above $1000 \mathrm{mg}$ as fruits with a high phenolic content, and those with 250 to $400 \mathrm{mg}$ GAE/100 g as fruits with an intermediate phenolic content. According to the ranges specified, and comparing our data with those of other oilseeds like hazelnut, walnut and pistachio (Arcan \& Yemenicioğlu, 2009), the baru almond and the pulp with its peel can be considered as fruit components with high phenolic concentrations (Table 2).

Regarding the antioxidant capacity, evaluated through ABTS, DPPH and FRAP assays, the raw almond had the highest antiradical capacity, and the values found in the roasted almond were $7 \%$ to $24 \%$ lower than those of the raw baru almond. Roasting may have decreased the antiradical capacity of the almond. A similar tendency was observed by Lemos et al. (2012), via the DPPH test, in raw baru almond $(288.4 \mu \mathrm{mol} \mathrm{TE} / \mathrm{g})$, as compared to the roasted $(149.1 \mu \mathrm{mol} \mathrm{TE} / \mathrm{g})$ almond (both with skin), whose values are higher than those found in our study.

The lowest values of antioxidant capacity were obtained in baru peel and pulp (Table 2). Considering the ABTS and DPPH results, the value of the pulp with its peel is comparable to that of baru almonds. Contreras-Calderón et al. (2011) reported

Table 2. Total phenolic compounds and antioxidant capacity assessed by different methods in the peel, pulp, and raw and roasted almonds (with skin) of the baru fruit (fresh weight) ${ }^{1}$.

\begin{tabular}{|c|c|c|c|c|}
\hline \multirow[t]{2}{*}{ Sample } & \multirow{2}{*}{$\begin{array}{l}\text { Total phenolics } \\
(\mathrm{mg} \mathrm{GAE} / 100 \mathrm{~g})\end{array}$} & \multicolumn{3}{|c|}{$\begin{array}{l}\text { Antioxidant capacity } \\
(\mu \mathrm{mol} \mathrm{TE} / \mathrm{g})\end{array}$} \\
\hline & & ABTS & $\mathrm{DPPH}$ & FRAP \\
\hline Peel & $477^{c} \pm 27$ & $60^{c} \pm 2$ & $45^{c} \pm 2$ & $50.0^{c} \pm 0.2$ \\
\hline Pulp & $292^{\mathrm{d}} \pm 1$ & $49^{d} \pm 2$ & $21.2^{\mathrm{d}} \pm 0.1$ & $24.2^{\mathrm{d}} \pm 0.2$ \\
\hline Raw almond & $1,107^{\mathrm{a}} \pm 44$ & $100^{\mathrm{a}} \pm 4$ & $81.0^{\mathrm{a}} \pm 0.8$ & $157^{a} \pm 3$ \\
\hline Roasted almond & $728^{b} \pm 41$ & $77.0^{\mathrm{b}} \pm 0.6$ & $76^{\mathrm{b}} \pm 1$ & $126.8^{\mathrm{b}} \pm 0.6$ \\
\hline
\end{tabular}

${ }^{1}$ Values are means \pm standard deviation $(n=3)$. In the same column, means with different letters differ significantly by Tukey test ( $\left.\mathrm{p} \leq 0.05\right)$. GAE: gallic acid equivalent, TE: Trolox equivalent. 
the antioxidant capacity value of $65.3 \mu \mathrm{mol} \mathrm{TE} / \mathrm{g}$ in cupuaçu peel, by the ABTS method, which was close to that of baru peel. Omena et al. (2012) analyzed the antioxidant capacity of peel from the Cerrado native fruits jenipapo, siriguela and umbu, by ABTS and FRAP methods, and all the values reported were lower than the antioxidant capacity of baru peel evaluated via the same methods (Table 2). The antioxidant capacity of baru pulp, by the ABTS assay, was higher than that of other Cerrado native fruits, such as jenipapo $(7.3 \mu \mathrm{mol} \mathrm{TE} / \mathrm{g})$, passion fruit $(10.8 \mu \mathrm{mol} \mathrm{TE} / \mathrm{g})$ and graviola $(35.9 \mu \mathrm{mol} \mathrm{TE} / \mathrm{g})$ (Souza et al., 2012). The values of antioxidant capacity of 33 conventional fruits (Chen et al., 2014), assessed by the FRAP method, were from 0.5 to $15.6 \mu \mathrm{mol} \mathrm{TE} / \mathrm{g}$, lower than that of baru pulp (Table 2).

The correlations between total phenolic compounds and antioxidant capacity were strong and significant for ABTS and FRAP results. Probably, phenolics are the main compounds responsible for the antioxidant capacity of baru fruit, mostly gallic acid, catechin and ferulic acid (Lemos et al., 2012), and tannin (Marin et al., 2009), as reported for baru almond. Furthermore, the significant correlations between the ABTS and FRAP, and between the FRAP and DPPH assays, suggest that the FRAP may be the most suitable method to assess the antioxidant capacity in these food matrices (Table 3). However, a combination of assays are recommended for the antioxidant capacity analysis, as ABTS and DPPH measure the scavenging capacity of reactive oxygen species, and FRAP determines the metal chelating capacity (Huang et al., 2005).

Concerning the DPPH test, the values found for raw and roasted almonds and for baru pulp with its peel were higher than those reported for the pulp of buriti (Mauritia flexuosa L.f.) native to the Amazon and Cerrado biomes (Cândido et al., 2015).

In order to verify if the antioxidant capacity of foods may be reproduced in vivo, studies about the effect of the antioxidant compounds on animal tissues should be carried out. The roasted baru almond protected tissues of male adult Wistar rats against oxidative stress (Fernandes et al., 2015; Siqueira et al., 2012). Moreover, Bento et al. (2014) reported that the daily intake of $20 \mathrm{~g}$ of roasted baru almond significantly reduced the serum concentrations of total cholesterol, LDL cholesterol and non-HDL cholesterol in mildly hypercholesterolemic subjects. Concerning the therapeutic use of the baru almond, we suggest in vivo studies using the combination of baru pulp and its peel to investigate the potential health-benefits related to its dietary fiber and polyphenol contents.

Table 3. Pearson's correlation coefficients between total phenolic compounds and antioxidant capacity (assessed by different methods) of the peel, pulp, raw and roasted almonds (with skin) of baru fruit.

\begin{tabular}{ccccc}
\hline Variables & Phenolics & ABTS & DPPH & FRAP \\
\hline Phenolics & 1 & - & - & - \\
ABTS & $0.9997^{1}$ & 1 & - & - \\
DPPH & $0.9237^{\text {ns }}$ & $0.9268^{\text {ns }}$ & 1 & $0.9753^{1}$ \\
FRAP & $0.9651^{1}$ & $0.9696^{1}$ & - & 1 \\
\hline
\end{tabular}

${ }^{1}$ Significant correlations at $\mathrm{p}<0.05{ }^{\text {ns }}$ : no significant correlations.

\section{Conclusion}

The combination of the peel and pulp of baru fruit provides high fiber, low energy, and similar phenolic content and antioxidant capacity when compared to the baru almond. The nutrients and phenolic contents of baru indicate the potential use of whole fruit (peel, pulp and almond) in healthy diets and as an ingredient of health foods. However, further studies are required to confirm their nutritional and health benefits, especially for the peel and pulp of baru.

\section{Acknowledgements}

The authors are grateful to the Universidade Federal de Goiás (UFG, Federal University of Goiás) and the Coordenação de Aperfeiçoamento de Pessoal do Nível Superior (CAPES, Coordination for the Improvement of Higher Education Personnel), for the financial support.

\section{References}

Alves, A. M., Fernandes, D. C., Borges, J. F., Sousa, A. G. O., \& Naves, M. M. V. (2016). Oil seeds native to the Cerrado have fatty acid profile beneficial for cardiovascular health. Revista de Nutrição, 29(6), 855-862. http://dx.doi.org/10.1590/1678-98652016000600010.

Alves, A. M., Mendonça, A. L., Caliari, M., \& Cardoso-Santiago, R. A. (2010). Avaliação química e física de componentes do baru (Dipteryx alata Vog.) para estudo da vida de prateleira. Pesquisa Agropecuária Tropical, 40(3), 266-273.

Association of Official Analytical Chemists - AOAC. (2010). Official methods of analysis of the Association of Official Analytical Chemists. Washington, DC: AOAC.

Arcan, I., \& Yemenicioğlu, A. (2009). Antioxidant activity and phenolic content of fresh and dry nuts with or without the seed coat. Journal of Food Composition and Analysis, 22(3), 184-188. http://dx.doi. org/10.1016/j.jfca.2008.10.016.

Bento, A. P. N., Cominetti, C., Simões, A. Fo., \& Naves, M. M. V. (2014). Baru almond improves lipid profile in mildly hypercholesterolemic subjects: a randomized, controlled, crossover study. Nutrition, Metabolism, and Cardiovascular Diseases, 24(12), 1330-1336. PMid:25149894. http://dx.doi.org/10.1016/j.numecd.2014.07.002.

Benzie, I. F. F., \& Strain, J. J. (1996). The ferric reducing ability of plasma (FRAP) as a measure of antioxidant power. Analytical Biochemistry, 239(1), 70-76. PMid:8660627.http://dx.doi.org/10.1006/abio.1996.0292.

Bligh, E. G., \& Dyer, W. J. A. (1959). Rapid method of total lipid extraction and purification. Canadian Journal of Biochemistry and Physiology, 37(8), 911-917. PMid:13671378. http://dx.doi.org/10.1139/o59-099.

Brand-Williams, W., Cuvelier, M. E., \& Berset, C. (1995). Use of a free radical method to evaluate antioxidant activity. LebensmittelWissenschaft + Technologie, 28(1), 25-30. http://dx.doi.org/10.1016/ S0023-6438(95)80008-5.

Cândido, T. L. N., Silva, M. R., \& Agostini-Costa, T. S. (2015). Bioactive compounds and antioxidant capacity of buriti (Mauritia flexuosa L.f.) from the Cerrado and Amazon biomes. Food Chemistry, 177, 313-319. PMid:25660891. http://dx.doi.org/10.1016/j.foodchem.2015.01.041.

Chen, G., Chen, S., Zhao, Y., Luo, C., Li, J., \& Gao, Y. (2014). Total phenolic contents of 33 fruits and their antioxidant capacities before and after in vitro digestion. Industrial Crops and Products, 57, 150 157. http://dx.doi.org/10.1016/j.indcrop.2014.03.018.

Collevatti, R. G., Telles, M. P. C., Nabout, J. C., Chaves, L. J., \& Soares, T. N. (2013). Demographic history and the low genetic diversity in Dipteryx alata (Fabaceae) from Brazilian Neotropical savannas. 
Heredity, 111(2), 97-105. PMid:23591520. http://dx.doi.org/10.1038/ hdy.2013.23.

Contreras-Calderón, J., Calderón-Jaimes, L., Guerra-Hernández, E., \& García-Villanova, B. (2011). Antioxidant capacity, phenolic content and vitamin $\mathrm{C}$ in pulp, peel and seed from 24 exotic fruits from Colombia. Food Research International, 44(7), 2047-2053. http:// dx.doi.org/10.1016/j.foodres.2010.11.003.

Crozier, A., Jaganath, I. B., \& Clifford, M. N. (2009). Dietary phenolics: chemistry, bioavailability and effects on health. Natural Product Reports, 26(8), 1001-1043. PMid:19636448. http://dx.doi.org/10.1039/ b802662a.

Czeder, L. P., Fernandes, D. C., Freitas, J. B., \& Naves, M. M. V. (2012). Baru almonds from different regions of the Brazilian Savanna: implications on physical and nutritional characteristics. Agricultural Science, 3(5), 745-754. http://dx.doi.org/10.4236/as.2012.35090.

Del Rio, D., Rodriguez-Mateos, A., Spencer, J. P. E., Tognolini, M., Borges, G., \& Crozier, A. (2013). Dietary (poly)phenolics in human health: structures, bioavailability, and evidence of protective effects against chronic diseases. Antioxidants \& Redox Signalling, 18(14), 1818-1892. PMid:22794138. http://dx.doi.org/10.1089/ars.2012.4581.

Fernandes, D. C., Alves, A. M., Castro, G. S. F., Jordão, A. A. Jr., \& Naves, M. M. V. (2015). Effects of baru almond and Brazil nut against hyperlipidemia and oxidative stress in vivo. Journal of Food Research, 4(4), 38-46. http://dx.doi.org/10.5539/jfr.v4n4p38.

Fernandes, D. C., Freitas, J. B., Czeder, L. P., \& Naves, M. M. V. (2010). Nutritional composition and protein value of the baru (Dipteryx alata Vog.) almond from the Brazilian Savanna. Journal of the Science of Food and Agriculture, 90(10), 1650-1655. PMid:20564449. http:// dx.doi.org/10.1002/jsfa.3997.

Freitas, D. G. C., Takeiti, C. Y., Godoy, R. L. O., Ascheri, J. L. R., Carvalho, C. W. P., Souza, P. L. M., Ribeiro, A. E. C., \& Ascheri, D. P. R. (2014). Extruded baru flour addition (Dipteryx alata Vog.) in cookie formulations: effect on consumer's acceptability. Acta Horticulturae, (1040), 89-96. http://dx.doi.org/10.17660/ActaHortic.2014.1040.11.

Freitas, J. B., \& Naves, M. M. V. (2010). Composição química de nozes e sementes comestíveis e sua relação com a nutrição e saúde. Revista de Nutrição, 23(2), 269-279. http://dx.doi.org/10.1590/S141552732010000200010.

Huang D., Ou B., Prior R.L. (2005). The chemistry behind antioxidant capacity assays. Journal of Agricultural and Food Chemistry, 53(6), 1841-1856.

Koehnlein, E. A., Koehnlein, E. M., Corrêa, R. C. G., Nishida, V. S., Correa, V. G., Bracht, A., \& Peralta, R. M. (2016). Analysis of a whole diet in terms of phenolic content and antioxidant capacity: effects of a simulated gastrointestinal digestion. International Journal of Food Sciences and Nutrition, 67(6), 614-623. PMid:27210900. http:// dx.doi.org/10.1080/09637486.2016.1186156.

Lemos, M. R. B., Siqueira, E. M. A., Arruda, S. F., \& Zambiazi, R. C. (2012). The effect of roasting on the phenolic compounds and antioxidant potential of baru nuts [Dipteryx alata Vog.]. Food Research International, 48(2), 592-597. http://dx.doi.org/10.1016/j. foodres.2012.05.027.

Lima, J. C. R., Freitas, J. B., Czeder, L. P., Fernandes, D. C., \& Naves, M. M. V. (2010). Qualidade microbiológica, aceitabilidade e valor nutricional de barras de cereais formuladas com polpa e amêndoa de baru. Boletim do Centro de Pesquisa e Processamento de Alimentos, 28(2), 331-343.

Marin, A. M. F., Siqueira, E. M. A., \& Arruda, S. F. (2009). Minerals, phytic acid and tannin contents of 18 fruits from the Brazilian savanna. International Journal of Food Sciences and Nutrition, 60(Suppl 7), 177187. PMid:19353365. http://dx.doi.org/10.1080/09637480902789342.

Marques, A., Chicaybam, G., Araujo, M. T., Manhães, L. R. T., \& Sabaa-Srur, A. U. O. (2010). Composição centesimal e de minerais de casca e polpa de manga (Mangifera indica L.). Revista Brasileira de Fruticultura, 32(4), 1206-1210. http://dx.doi.org/10.1590/S010029452010005000117.

Mazzeo, T., N'dri, D., Chiavaro, E., Visconti, A., Fogliano, V., \& Pellegrini, N. (2011). Effect of two cooking procedures on phytochemical compounds, total antioxidant capacity and color of selected frozen vegetables. Food Chemistry, 128(3), 627-633. http://dx.doi. org/10.1016/j.foodchem.2011.03.070.

Omena, C. M. B., Valentim, I. B., Guedes, G. S., Rabelo, L. A., Mano, C. M., Bechara, E. J. H., Sawaya, A. C. H. F., Trevisan, M. T. S., Costa, J. G., Ferreira, R. C. S., Sant’ana, A. E. G., \& Goulart, M. O. F. (2012). Antioxidant, anti-acetylcholinesterase and cytotoxic activities of ethanol extracts of peel, pulp and seeds of exotic Brazilian fruits. Food Research International, 49(1), 334-344. http://dx.doi.org/10.1016/j. foodres.2012.07.010.

Re, R., Pellegrini, N., Proteggente, A., Pannala, A., Yang, M., \& RiceEvans, C. (1999). Antioxidant activity applying an improved ABTS radical cation decolorizations assay. Free Radical Biology \& Medicine, 26(9-10), 1231-1237. PMid:10381194. http://dx.doi.org/10.1016/ S0891-5849(98)00315-3.

Rocha, L. S., \& Santiago, R. A. C. (2009). Implicações nutricionais e sensoriais da polpa e casca de baru (Dipterix Alata vog.) na elaboração de pães. Ciência e Tecnologia de Alimentos, 29(4), 820-825. http:// dx.doi.org/10.1590/S0101-20612009000400019.

Singleton, V. L., \& Rossi, J. A. (1965). Colorimetry of total phenolics with phosphomolybidic-phosphotungstic acid reagents. American Journal of Enology and Viticulture, 16, 144-158.

Siqueira, E. M. A., Marin, A. M. F., Cunha, M. S. B., Fustinoni, A. M., Sant'ana, L. P., \& Arruda, S. F. (2012). Consumption of baru seeds [Dipteryx alata Vog.], a Brazilian savanna nut, prevents iron-induced oxidative stress in rats. Food Research International, 45(1), 427-433. http://dx.doi.org/10.1016/j.foodres.2011.11.005.

Soares, T. N., Chaves, L. J., Telles, M. P. C., Diniz-Filho, J. A. F., \& Resende, L. V. (2008). Distribuição espacial da variabilidade genética intrapopulacional de Dipteryx alata. Pesquisa Agropecuária Brasileira, 43(9), 1151-1158. http://dx.doi.org/10.1590/S0100204X2008000900008.

Sousa, A. G. O., Fernandes, D. C., Alves, A. M., Freitas, J. B., \& Naves, M. M. V. (2011). Nutritional quality and protein value of exotic almonds and nut from the Brazilian Savanna compared to peanut. Food Research International, 44(7), 2319-2325. http://dx.doi. org/10.1016/j.foodres.2011.02.013.

Souza, V. R., Pereira, P. A. P., Queiroz, F., Borges, S. V., \& Carneiro, J. D. S. (2012). Determination of bioactive compounds, antioxidant activity and chemical composition of Cerrado Brazilian fruits. Food Chemistry, 134(1), 381-386. http://dx.doi.org/10.1016/j. foodchem.2012.02.191.

Takemoto, E., Okada, I. A., Garbelotti, M. L., Tavares, M., \& AuedPimentel, S. (2001). Composição química da semente e do óleo de baru (Dipteryx alata Vog.) nativo do Município de Pirenópolis, Estado de Goiás. Revista do Instituto Adolfo Lutz, 60(2), 113-117.

Vasco, C., Ruales, J., \& Kamal-Eldin, A. (2008). Total phenolic compounds and antioxidant capacities of major fruits from Ecuador. Food Chemistry, 111(4), 816-823. http://dx.doi.org/10.1016/j.foodchem.2008.04.054.

Vieira, R. F., Agostini-Costa, T. S., Silva, D. B., Sano, S. M., \& Ferreira, F. R. (2010). Frutas nativas da região centro-oeste do Brasil. Brasília: Embrapa.

Zhang, W., Huang, W., Chen, W., Han, L., \& Zhang, H. (2014). Optimization of extraction conditions of areca seed polyphenols and evaluation of their antioxidant activities. Molecules (Basel, Switzerland), 19(10), 16416-16427. PMid:25314603. http://dx.doi. org/10.3390/molecules191016416. 